\title{
IMPLEMENTASI \\ PERATURAN WALIKOTA KENDARI NOMOR 13 TAHUN 2008 TENTANG PENATAAN PEDAGANG KAKI LIMA DI KOTA KENDARI
}

\author{
${ }^{1}$ Rian Supriadin S, ${ }^{2}$ Syamsul Alam, ${ }^{3}$ La Ode Muhammad Elwan \\ Fakultas IImu Sosial dan IImu Politik Universitas Halu Oleo \\ rsupriadin79@gamil.com, syamsulalam330@uho.ac.id, muh.elwan@uho.ac.id \\ Kendari, Sulawesi Tenggara, Indonesia
}

\begin{abstract}
The purpose of this research is to find out the Implementation of Kendari Mayor Regulation No. 13 of 2008 concerning the Arrangement of Street Vendors in Kendari City (Study of Mandonga District), as well as the Factors that influence the Implementation of Street Vendor Merchant management policies in Mandonga District and the Constraints faced by the City Government Kendari in the Arrangement of Street Vendors in Mandonga District. The method used in this research is descriptive qualitative research method. All data in this study were obtained from interviews, observations and documentation. Based on what has been described in the results of the study, it can be concluded that in the implementation of the policy of the Mayor of Kendari Number 13 of 2008 concerning the arrangement of Street Vendors in Mandonga District conducted by related agencies namely the Department of Commerce, Cooperatives and SMEs of the City of Kendari, Civil Service Police Unit Praja Kendari City and Each Camat in Kendari City can be said to have not been maximized due to the lack of precise goals, aims and objectives of the policy regulated in Kendari Mayor Regulation No. 13 of 2008 concerning the arrangement of Street Vendors, which resulted in street vendors doing their activities not in their place or a place that is legalized by the Kendari City Government.
\end{abstract}

Keywords: Mayor Regulations; Policy Implementation; Street vendors.

\begin{abstract}
Abstrak
Tujuan penelitiannya adalah untuk mengetahui Implementasi Peraturan walikota Kendari Nomor 13 Tahun 2008 Tentang Penataan Pedagang Kaki Lima Di Kota Kendari (studi Kecamatan Mandonga), serta Faktor- Faktor yang mempengaruhi Implementasi kebiajakan penataan PKL di Kecamatan Mandonga dan Kendala-kendala yang dihadapi Pemerintah Kota Kendari dalam Penataan Pedagang Kaki Lima di Kecamatan Mandonga.. Metode yang digunakan dalam penelitian ini adalah metode penelitian deskriptif kualitatif. Keseluruhan data dalam penelitian ini diperoleh dari wawancara, observasi dan dokumentasi. Berdasarkan uraian hasil penelitian, maka dapat ditarik kesimpulan bahwa dalam implementasi kebijakan Peraturan Walikota Kendari Nomor 13 tahun 2008 tentang penataan Pedagang Kaki Lima di Kecamatan Mandonga yang dilakukan oleh instansi terkait yaitu Dinas Perdagangan, Koperasi dan UKM Kota Kendari, Satuan Polisi Pamong Praja Kota Kendari dan Masing-masing Camat se Kota Kendari bisa dikatakan belum maksimal dikarenakan belum tepatnya tujuan, maksud dan sasaran kebijakan yang diatur dalam Peraturan Walikota Kendari Nomor 13 tahun 2008 tentang Penataan Pedagang Kaki Lima, yang mengakibatkan Pedagang kaki Lima melakukan aktivitasnya bukan pada tempatnya sesuai arahan Pemerintah Kota Kendari.
\end{abstract}

Kata Kunci: Implementasi Kebijakan;Peraturan Walikota; Pedagang Kaki Lima.

Open Access at: http://ojs.uho.ac.id/index.php/PUBLICUHO/index

Journal Publicuho is licensed under a Creative Commons Attribution 4.0 International License. 


\section{PENDAHULUAN}

Upaya penataan Pedagang Kaki Lima (PKL) yang terjadi di Kota Kendari yang dilakukan para aparat berdasarkan Peraturan Walikota Kendari Nomor: 13 tahun 2008 tentang Pelaksanaan Peraturan Daerah Kota Kendari tahun 2007 tentang Penataan Pedagang Kaki Lima disebut bahwa "setiap orang atau badan dilarang berdagang, berusaha dibagian jalan/trotoar, halte, dan tempat-tempat untuk kepentingan umum lainnya di luar ketentuan sebagaimana dimaksud". Penataan Pedagang Kaki Lima adalalah kegiatan yang dilakukan dalam rangka mengatur kawasan, lokasi, waktu, jenis barang yang diperdagangkan, alat peraga dan batasan Pedagang Kaki Lima di kawasan tertentu.

Kehadiran Pedagang Kaki Lima di Kota Kendari tidak hanya memberikan dampak positif untuk pertumbuhan Kota salah satunya yaitu menopang perekonomian masyarakat kelas bawah serta penyedia barang bagi kelas atas, tetapi juga memunculkan permasalahan di Kota seperti halnya Keberadaan Pedagang Kaki Lima kerap dianggap ilegal karena menempati ruang publik dan tidak sesuai dengan visi kota yang sebagian besar menekankan aspek kebersihan, keindahan dan kerapihan Kota. Oleh karena itu, Pedagang Kaki Lima ini seringkali menjadi target utama dalam hal realisasi kebijakankebijakan pembangunan yang dibuat Pemerintah Kota sehingga pedagang kaki lima (PKL) menjadi target utama Pemerintah dalam masalah kebijakan,seperti penggusuran, penataan dan relokasi bagi Pedagang Kaki Lima yang belum tertib dan teratur.

Permasalahan Pedagang Kaki Lima di perkotaan khususnya di Kota Kendari adalah banyaknya pedagang yang menjual barang dagangnya bukan pada tempatnya contohnya jalan/trotoar, halte, dan tempat-tempat untuk kepentingan umum. Keberadaan Pedagang Kaki Lima di Kota Kendari merupakan suatu fenomena yang banyak terjadi di Kota-kota besar lainnya. Banyaknya Pedagang Kaki Lima menimbulkan kemacetan arus lalu lintas dan jelas akan menghasilkan sampah dan hal inilah yang menyebabkan kota menjadi semrawut, tidak bersih, indah, dan nyaman. Selain itu berpotensi menimbulkan kerawanan sosial, sehingga diperlukan penataan Pedagang Kaki Lima yang lebih baik.

Berdasarkan fenomena diatas maka peneliti menganggap masalah implementasi kebijakan penataan Pedagang Kaki Lima perlu untuk dikaji. Oleh karena itu, maka penulis mengangkat judul: Implementasi Peraturan walikota Kendari Nomor 13 Tahun 2008 Tentang Penataan Pedagang Kaki Lima di Kota Kendari (studi Kecamatan Mandonga).

Berdasarkan tujuan penelitian dan fokus kajian, berikut dijelaskan kajian literatur yang berhubungan dengan Implementasi Peraturan walikota Kendari Nomor 13 Tahun 2008 Tentang Penataan Pedagang Kaki Lima di Kota Kendari. Tentunya, untuk lebih mamahami subtansi implementasi kebijakan maka perlu menejelaskan kontribusi keilmuan terhadap kajian dalam penelitian ini dengan memberikan konseptualisasi berdasarkan indikator/instrumen penelitian yang digunakan sehingga kita memiliki pemahaman dan 
tindakan yang sama dalam memaknai implementasi kebijakan. Secara detil dijelaskan sebagai berikut:

\section{Kebijakan Publik}

Menurut Thomas R Dye (dalam Wayne Parsons, 2005: xi) "public policy is whatever governments choose to do or not to do" kebijakan publik sebagai "apapun pilihan pemerintah untuk melakukan atau tidak melakukan. Dalam upaya mencapai tujuan negara, pemerintah perlu mengambil pilihan tindakan yang dapat berupa melakukan sesuatu atau tidak melakukan sesuatu. Keduanya, menurut definisi Dye, merupakan kebijakan publik karena merupakan upaya mencapai tujuan tertentu dan keduanya memiliki dampak terhadap masyarakat (Elwan, L.O.M, 2011:15) Senada dengan pandangan Dye, Edwards dan Sharkansky dalam Kismartini (2008:16) mengemukakan bahwa kebijakan publik adalah apa yang dinyatakan dan dilakukan atau tidak dilakukan oleh pemerintah yang dapat ditetapkan dalam peraturan-peraturan perundang-undangan, atau dalam policy statement yang berbentuk pidato-pidato, dan wacana yang diungkapkan pejabat politik dan pejabat pemerintah yang segera ditindaklanjuti dengan program-program dan tidakan pemerintah. Menurut Jones dalam Wahab (2005:65) kebijakan publik adalah suatu tindakan bersanksi yang mengarah pada tujuan tertentu yang diarahkan pada suatu masalah tertentu yang saling berkaitan yang memepengaruhi sebagian besar masyarakat. Berikutnya Riant Nugroho (2008:10) mendefinisikan kebijakan publik adalah keputusan yang dibuat oleh negara, khususnya pemerintah, sebagai strategi untuk merealisasikan tujuan negara yang bersangkutan. Kebijakan publik adalah strategi untuk mengantar masyarakat

\section{Implementasi Kebijakan}

Menurut Charles $O$. Jones, ada tiga aktivitas atau proses yang penting dalam implementasi suatu kebijakan, yaitu meliputi:

\section{Tahapan Pengorganisasian (Organized)}

Tahapan pengorganisasian lebih mengarah kepada proses kegiatan pengaturan dan penetapan siapa yang menjadi pelaksana kebijakan (penentuan lembaga organisasi) yang meliputi tugas pokok, fungsi, kewenangan, dan tanggung jawab, koordinasi implementasi kebijakan, menetapkan anggaran, menetapkan sarana dan prasarana yang diperlukan untuk pelaksanaan kebijakan agar sesuai dengan harapan yang diinginkan.

\section{Tahapan Interpretasi (Interpretation)}

Tahapan Interpretasi merupakan tahapan penjabaran sebuah kebijakanyang lebih bersifat abstrak ke dalam kebijakan yang lebih bersifat teknis operasional. Aktivitas ini juga diikuti kegiatan mengkomunikasikan kebijakan (sosialisasi) agar seluruh elemen masyarakat (stakeholder) dan kelompok sasaran dapat mengetahui dan memahami arah, tujuan, dan sasaran kebijakan. 


\section{Tahapan Aplikasi (Application)}

Tahap Aplikasi merupakan tahap penerapan rencana proses implementasi kebijakan ke dalam realitas nyata. Tahap aplikasi merupakan perwujudan dari pelaksanaan masingmasing kegiatan dalam tahapan yang telah disebutkan sebelumnya. Tahap aplikasi merupakan tahap paling akhir karena pada tahap ini dapat dilihat apakah kebijakan tersebut hanya sebuah rumusan kebijakan atau penafsiran mengenai kebijakan yang abstrak atau bisa diimplementasikan dan dapat menjawab tantangan berbagai permasalahan yang terjadi dalam masyarakat secara keseluruhan.

Demikian halnya menurut Jones (1991) dalam La Ode Muhammad Elwan, (2011: 18) menjelaskan bahwa Implementasi kebijakan mudah dimengerti secara teoritik dan konseptual, namun tidak senantiasa demikian dalam bentuknya yang kongkrit, karena pelaksanaannya secara nyata bukanlah sesuatu yang mudah.

Dalam mengkaji studi implementasi kebijakan publik maka perlu diketahui variabel-variabel atau faktor yang mempengaruhinya. Ada beberapa model implementasi yang dapat digunakan sebagai acuan, diantaranya adalah sebagai berikut;

Grindle (1980) mendekati implementasi kebijakan sebagai suatu proses tindakan-tindakan administratif umum yang perlu diperiksa sampai level program yang spesifik. Keberhasilan atau kegagalan dari suatu kebijakan dapat dilihat dari kapasitasnya untuk menjalankan program sesuai dengan desain semula. Karena itu, implementasi kebijakan secara keseluruhan perlu dilihat dengan mempertanyakan apakah pelaksanaan kebijakan sesuai dengan yang ditentukan (dalam Elwan.L.O.M, 2011:22). Pengukuran kesesuaian ini dapat dilihat dari dua hal, yaitu: a) Dilihat dari prosesnya, yakni yang dapat diperiksa pada tingkat program yang spesifik dan dana yang dialokasikan, serta b) Dilihat dari hasil yang dicapai oleh implementasinya kebijakan tersebut. Dimensi ini diukur dengan melihat dua faktor, yaitu: a) Dampak atau efeknya pada masyarakat secara individu dan kelompok; dan b) Tingkat perubahan yang terjadi serta penerimaan kelompok sasaran terhadap perubahan yang terjadi. Lebih lanjut, menurut argumen Grindle (dalam Elwan.L.O.M, 2011: 22) bahwa keberhasilan suatu implementasi kebijakan publik amat ditentukan oleh derajat dapat tidaknya kebijakan itu diterapkan atau implementabilitas (implementability) dari kebijakan tersebut. Implementabilitas ini dapat dilihat dari aspek isi kebijakan (content of policy) dan aspek konteks implementasi kebijakan (contexs of policy implementation).

\section{Faktor-Faktor yang mempengaruhi Implementasi Kebijakan}

Untuk memberikan gambaran fokus kajian ini, berikut dijelaskan beberapa faktor-faktor yang mempengaruhi implementasi kebijakan berdasarkan model yang digunakan.

\section{Model Daniel Mazmanian dan Paul A. Sabatier.}

Mazmanian dan Sabatier (dalam Putra, 2009:26) melihat implementasi kebijakan merupakan fungsi dari tiga variable, yaitu : 1. Karakteristik dari Masalah (tractability of the problems); 2. 
Karakteristik Kebijakan/ undang-undang (ability of statute to structure implementation); 3. Variabel Lingkungan (non statutory variables affecting implementation). Pemikiran Sabatier dan Mazmanian ini berkesan menganggap bahwa suatu implementasi akan efektif apabila birokrasi pelaksananya mematuhi apa yang telah digariskan oleh peraturan (petunjuk pelaksanaan, petunjuk tekhis). Oleh karena itulah model ini disebut sebagai model top down. Dengan pendekatan semacam ini sudah seharusnya tujuan dan sasaran yang akan dituju hendaknya dituangkan dalam program maupun proyek yang jelas, dan mudah dipahami sehingga para birokrat akan mudah untuk memahaminya kemana arah tujuan atau sasaran yang hendak dituju.

\section{Model George C. Edwards III}

Edward III (dalam Subarsono, 2011: 90-92) berpandangan bahwa implementasi kebijakan dipengaruhi oleh empat variabel, yaitu:

1) Komunikasi, yaitu keberhasilan implementasi kebijakan mensyaratkan agar implementor mengetahui apa yang harus dilakukan, dimana yang menjadi tujuan dan sasaran kebijakan harus ditransmisikan kepada kelompok sasaran (target group), sehingga akan mengurangi distorsi implementasi.

2) Sumber daya, meskipun isi kebijakan telah dikomunikasikan secara jelas dan konsisten, tetapi apabila implementor kekurangan sumberdaya untuk melaksanakan, maka implementasi tidak akan berjalan efektif. Sumber daya tersebut dapat berwujud sumber daya manusia, misalnya kompetensi implementor dan sumber daya finansial.

3) Disposisi, adalah watak dan karakteristik yang dimiliki oleh implementor, seperti komitmen, kejujuran, sifat demokratis. Apabila implementor memiliki disposisi yang baik, maka implementor tersebut dapat menjalankan kebijakan dengan baik seperti apa yang diinginkan oleh pembuat kebijakan. Ketika implementor memiliki sikap atau perspektif yang berbeda dengan pembuat kebijakan, maka proses implementasi kebijakan juga menjadi tidak efektif.

4) Struktur Birokrasi, Struktur organisasi yang bertugas mengimplementasikan kebijakan memiliki pengaruh yang signifikan terhadap implementasi kebijakan. Aspek dari struktur organisasi adalah Standard Operating Procedure (SOP) dan fragmentasi. Struktur organisasi yang terlalu panjang akan cenderung melemahkan pengawasan dan menimbulkan red-tape, yakni prosedur birokrasi yang rumit dan kompleks, yang menjadikan aktivitas organisasi tidak fleksibel.

Berdasarkan kajian literatur, maka arahan implementasi Peraturan walikota Nomor 13 Tahun 2008 tentang PKL Penataan Pedagang Kaki Lima di Kota Kendari sedapat mungkin menyesuaikan dengan subtansi (konten dan konteks) implementasi kebijakan sesuai indikator penelitian yang ditetapkan. Sejauh ini, jika kita mengkaji amanah Peraturan 
walikota Nomor 13 Tahun 2008 tentang PKL Penataan Pedagang Kaki Lima pada pasal 1 ayat 9 Pedagang Kaki Lima yang selanjutnya disingkat PKL adalah pedagang yang menjalankan kegiatan usahanya dalam jangka waktu tertentu dengan mempergunakan sarana atau perlengkapan yang mudah dipindahkan, dibongkar pasang dan mempergunakan lahan fasilitas umum sebagai tempat usahanya dengan maksud dan tujuan sebagaimana yang tertera pada pasal 2 Peraturan walikota No 13 Tahun 2008:

1) Penataan dan Pemberdayaan PKL dimaksudkan untuk memberikan kepastian usaha, perlindungan serta pengembangan usaha Pedagang Kaki lima yang tertib. teratur, aman, serasi, selaras dan seimbang dengan lingkungannya,

2) Penataan dan Pemberdayaan PKL bertujuan untuk:

a. Mewujudkan PKL sebagai pelaku usaha kecil yang terdaftar dan berhak mendapat perlindungan dan pembinaan sehingga dapat melakukan kegiatan usahanya pada lokasi yang ditetapkan;

b. Mengembangkan ekonomi selctor informal melalui pembinaan PKL serta mewujudkan harmonisasi keberadaan PKL dengan lingkungannya.

3) Sasaran penataan dan pemberdayaan PKL:

a. terciptanya ketertiban umum;

b. terwujudnya tertib hukum;

c. terciptanya keseimbangan, keselarasan dan keserasian keberadaan PKL dengan lingkungannya;

d. meningkatkan kinerja usaha PKL menjadi kelompok yang resmi sebagai sasaran binaan;

e. terwujudnya dukungan ruang bagi keberadaan PKL;

f. terciptanya keberadaan PKL yang harmonis dengan kegiatan usaha lain.

\section{Penataan Pedagang Kaki Lima}

Menurut Peraturan Menteri Dalam Negeri Republik Indonesia Nomor 41 Tahun 2012 Tentang Pedoman Penataan Dan Pemberdayaan Pedagang Kaki Lima Pedagang Kaki Lima, yang selanjutnya disingkat PKL, adalah pelaku usaha yang melakukan usaha perdagangan dengan menggunakan sarana usaha bergerak maupun tidak bergerak, menggunakan prasarana kota, fasilitas sosial, fasilitas umum, lahan dan bangunan milik pemerintah dan/atau swasta yang bersifat sementara/tidak menetap. Menurut Karafir (2007) pedagang kaki lima adalah pedagang yang berjualan di suatu tempat umum seperti tepi jalan, tamantaman, emper-emper toko dan pasar-pasar tanpa atau adanya izin usaha dari pemerintah. (Hamlan, 2014:31. Selanjutnyan, diadobsi dalam Peraturan Walikota Nomor 13 Tahun 2008 tentang PKL Penataan Pedagang Kaki Lima, Penataan adalah kegiatan yang dilakukan dalam rangka mengatur kawasan, lokasi, waktu, jenis barang yang diperdagangkan, alat peraga dan batasan PKL dikarvasan tertentu. Relokasi merupakan dimana membangun 
kembali tempat yang baru, harta kekayaan, termasuk tanah produktif dan prasarana umum di lokasi atau lahan lain, dalam relokasi adanya obyek dan subyek yang terkena pajak didalam perencaan dan pembangunan lokasi. Secara harfiah relokasi pasar adalah penataan ulang pada tempat yang baru atau pemindahan dari tempat lama ke tempat yang baru (Dian dan Utari, 2017:1255). Kajian tentang Pedagang Kali Lima, juga dijelaskan oleh McGee dan Yeung (2000), Pedagang Kaki Lima mempunyai pengertian yang sama dengan "hawkers", yang didefinisikan sebagai orang-orang yang menawarkan barang dan jasa untuk dijual di tempat umum, terutama di pinggir jalan dan trotoar. Pedagang adalah mereka yang melakukan perbuatan perniagaan (perdagangan) sebagai pekerjaannya sehari-hari. Pedagang kaki lima merupakan pedagang atau orang yang melakukan kegiatan atau usaha kecil tanpa didasari atas ijin dan menempati pinggiran jalan (trotoar) untuk menggelar dagangan. Menurut Evens dan Korff2, "definisi pedagang kaki lima adalah bagian dan sektor informal kota yang yang mengebangkan aktivitas produksi barang dan jasa di luar kontrol pemerintah dan tidak terdaftar". Demikian halnya dengan Wiego (2009) menyatakan bahwa terdapat beberapa paradigma terhadap Pedagang Kaki Lima (PKL) antara lain adalah :

1) Sektor informal adalah ekonomi tradisional yang akan mati dengan pertumbuhan industri modern. Produktivitasnya hanya marginal.

2) Keberadaaannya terpisah dari ekonomi formal.

3) Mencerminkan surplus tenaga kerja.

4) Sebagian besar sektor ini adalahpengusaha bisnis ilegal atau tidak terdaftar untuk menghindari regulasi dan pajak.

5) Pekerjaan pada ekonomi informal sebagian besar terdiri dari aktivitas untuk bertahan hidup dengan demikian bukan menjadi subyek kebijakan ekonomi.

6) Terutama terdiri dari usaha tidak terdaftar, pedagang jalanan, dan produsen skala

7) sangat kecil.

8) Tidak teregulasi.

9) Karena tidak teregulasi dan tidak kena pajak sebagian yang bekerja pada sektor informal adalah tidak sejahtera.

10) Tidak berkontribusi terhadap pertumbuhan ekonomi. (Hamlan, 2014:32) 
Gambar 1. Kerangka Pikir Penelitian

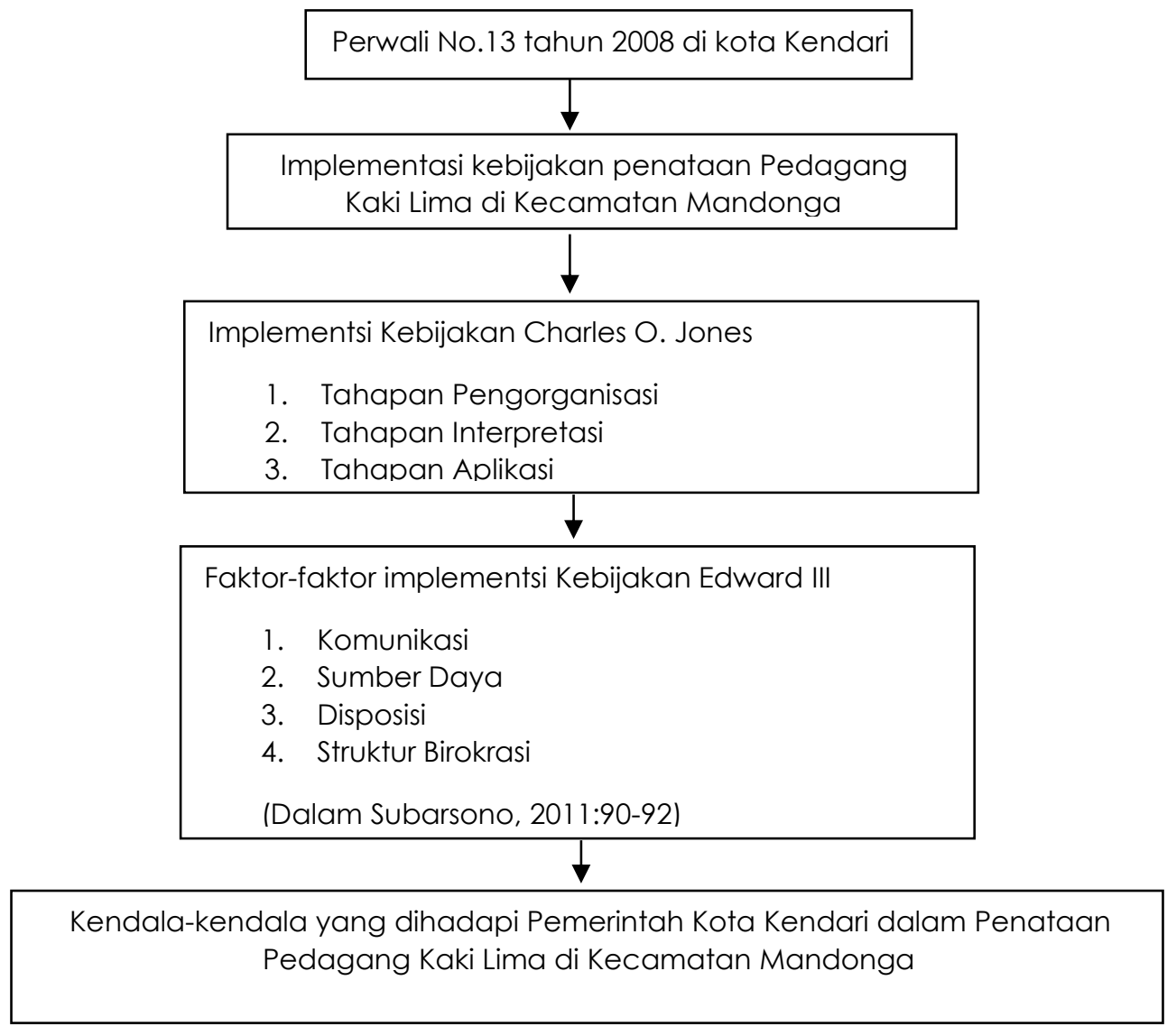

Sumber: dikembangkan penulis, 2020

\section{METODOLOGI}

Metode penelitian yang digunakan dalam pnelitian ini adalah metode penelitian kualitatif. Menurut bogdan dan taylor (Moleong,2007), metode penelitian kualitatif adalah prosedur penelitian yang menghasilkan data deskriptif yang berupa kata-kata tertulis atau lisan dari orangorang dan perilaku yang diamati. Menurut Ridjal (Bugin, 2001), metode kualitatif bertujuan untuk menggali atau membangun situasi proposisi atau menjelaskan makna dibalik sebuah realita. Metode penelitian kualitatif digunakan dalam penelitian ini untuk mengetahui dan menjelaskan tentang Implementasi Kebijakaan Penataan Pedagang Kaki Lima di Kota Kendari.

Informan penelitian adalah orang yang dimanfaatkan untuk memberikan informasi tentang situasi dan kondisi latar belakang penelitian (Moleong 2000:97).. Informan merupakan orang yang benar-benar mengetahui permasalahan yang akan diteliti. Jadi secara tidak langsung informan dalam penelitian ini untuk mengetahui bagaimana Implementasi Penwali Kendari Nomor 13 Tahun 2008 Dalam Penataan Pedagang Kaki Lima Di Kecamatan Mandonga Kota Kendari adalah Kepala Sat Pol PP Kota Kendari dan Kepala Bidang Penegakkan Perda Sat Pol PP Kota Kendari, Kepala Bidang UKM dan staf Dinas Perdagangan, Koperasi dan UKM Kota Kendari, Camat Mandonga dan Pedagang Kaki Lima sebanyak 3 orang. 
Untuk memperoleh data yang relevan dengan masalah ini, maka digunakan teknik pengumpulan data melalui (1) Observasi, menurut Hadi (1986) mengemukakan bahwa, observasi merupakan suatu proses yang kompleks, suatu proses yang tersusun dari berbagai proses biologis dan psikologis. Demi kelancaran penelitian, peneliti berusaha agar yang diamati tidak mengetahui atau merasa diamati. Karena jika mereka tahu, maka mereka akan curiga sehingga tingkah lakunya mungkin akan dibuat-buat atau tidak wajar lagi supaya dicatat oleh peneliti sebagai tingkah laku yang baik atau sebaliknya (Nawawi, 1983: 104); (2) Wawancara, wawancara atau interview merupakan percakapan dengan maksud tertentu (Moleong, 2005: 186); (3) Dokumentasi,

Teknik pengumpulan data dalam dokumentasi adalah pengambilan data yang diperoleh melalui dokumen-dokumen. Dokumen adalah setiap pernyataan tertulis yang disusun oleh seorang atau lembaga untuk keperluan penguji peristiwa (Moleong, 2007:161). Dari dokumen tersebut kemudian dilakukan pengkajian terhadap isinya, sehingga diperoleh kesimpulan (Moleong, 2002: 163).

Teknik yang digunakan dalam penelitian ini adalah menggunakan teknik induktif yang dilakukan dari awal sampai akhir pengumpulan data yang bersifat terbuka. Analisis data ini digunakan untuk menilai menganalisis data yang telah difokuskan dalam penelitian yaitu mengenai Implementasi Penwali No 13 Tahun 2008 tentang PKL Penataan Pedagang Kaki Lima di kota kendari dengan cara menganalisis dan menyajikan dalam bentuk data deskriptif melalui langkah-langkah dalam menganalisis data sebagai berikut: Reduksi Data, Unitasi dan Kategorisasi, Display Data dan penarikan kesimpulan.

\section{HASIL DAN PEMBAHASAN}

Menurut McGee dan Yeung (2000), Pedagang Kaki Lima mempunyai pengertian yang sama dengan "hawkers", yang didefinisikan sebagai orang-orang yang menawarkan barang dan jasa untuk dijual di tempat umum, terutama di pinggir jalan dan trotoar. Pedagang Kaki Lima juga merupakan salah satu pelaku usaha ekonomi mikro yang banyak ditemui di berbagai Daerah hingga Negara, seperti halnya yang ada di Kota Kendari, terkhusus di kecamatan mandonga. Keberadaan Pedagang Kaki Lima tentu menjadi hal yang tidak asing dan menjadi suatu hal yang tidak dapat dicegah. Hal ini di akibatkan karena menjadi Pedagang Kaki Lima tidak dibutuhkan pendidikan yang tinggi dan kemampuan yang terlalu hebat, hal inilah yang menjadi alasan banyaknya masyarakat yang tergiur untuk membentuk usaha berskala mikro seperti menjadi Pedagang Kaki Lima. Seperti hasil wawancara

"memang Pedagang Kaki Lima sudah menjadi dinamika kota yang mana mereka berjualan di bahu jalan dan trotoar, dan problemnya juga pedagang kaki lima ababila snudah mapan di tempat itu dan sudah menemukan hasil di tempat itu susah memang mau pindah walaupun sudah di atur dengan perda itu" (sumber: Ketua Asosiasi Pedagang Kaki Lima Kota Kendari, wawancara 13 januari 2020.) 


\section{IMPLEMENTASI PERATURAN WALIKOTA KENDARI NOMOR 13 TAHUN 2008 TENTANG PENATAAN PEDAGANG KAKI LIMA DI KOTA KENDARI}

Secara umum Pedagang Kaki Lima yang ada di kecamatan Mandonga ada yang menawarkan barang dan jasa. Dalam kawasan penelitian di Kecamatan Mandonga terdapat sarana umum atau publik yang cukup membuat kawasan tersebut menjadi ramai. Keberadaan pusat perbelanjaan Mall Mandonga, Pasar basah mandonga, Taman Kantor Wali Kota Kendari yang menjadi daya tarik sendiri di kawasan ini dan bukan hanya disitu saja ada beberapa tempat keberadaan Pedagang Kaki Lima seperti data yang diperoleh pada Tabel 1.

Tabel 1. Lokasi llegal Pedagang Kaki Lima di Kecamatan Mandonga

\begin{tabular}{|c|c|c|}
\hline No & Lokasi PKL & Keterangan \\
\hline 1 & Jl. Laute 2 (sepanjang jalan pasar lawata) & Lokasi yang dilarang \\
\hline 2 & Jl. Balai Kota (depan RRI) & Lokasi yang dilarang \\
\hline 3 & Jl. Lasandara (samping Mall Mandonga) & Lokasi yang dilarang \\
\hline 4 & Jl.Taridala (samping Korem) & Lokasi yang dilarang \\
\hline 5 & Jl. Raden Soeprapto & Lokasi yang dilarang \\
\hline 6 & Jl. Bina guna & Lokasi yang dilarang \\
\hline 7 & JI.Saranani (simpang empat kampus STIE 66) & Lokasi yang dilarang \\
\hline 8 & (Bundaran Mandonga) & Lokasi yang dilarang \\
\hline
\end{tabular}

Dari tabel 1 menjelaskan bahwa Pedagang Kaki Lima untuk di Kecamatan Mandonga tersebar di 8 lokasi, dimana 8 lokasi tersebut dilarang oleh pemerintah kota karena memang kenyataannya pedagang kaki lima menggunakan fasilitas umum seperti jalan dan trotoar untuk beraktiitas. Sesuai hasil obserasi peneliti bahwa ada 3 lokasi yang paling banyak Pedagang Kaki Lima melakukan aktiitasnya yaitu di Jl. Laute 2 (sepanjang jalan pasar lawata), Jl. Lasandara (samping Mall Mandonga) dan Jl.Taridala (samping Korem), karena memang lokasi-lokasi tersebut dekat dengan sarana umum yang cukup membuat kawasan tersebut menjadi ramai.

\section{Potret Penataan Pedagang Kaki Lima di Kota Kendari}

Keberadaan Pedagang Kaki Lima di Kecamatan Mandonga yang menempati fasilitas umum menjadi masalah tersendiri bagi pemerintah kota khususnya pemerintah Kota Kendari. Banyaknya jumlah pedagang kaki lima yang menggelar dagangannya di pinggir jalan dan trotoar menimbulkan banyak keluhan dari masyarakat dan mengurangi keindahan kota. Hal ini diperkuat dengan hasil wawancara

"Sebenarnya pedagang kaki lima ini bisa berdampak positif, hanyakan perlu di tata oleh pemerintah agar tidak mengganggu ketertiban umum, seperti larangan berjualan dipinggir jalan dan trotor karena memang akan menimbulkan kemacetan dan kurang baiknya tata ruang kota" (sumber: Masyarakat umum, wawancara 12 januari 2020)

Keberadaan Pedagang Kaki Lima yang banyak menimbulkan masalah baik dari segi kebersihan, tata tertib, dan kenyamanan masyarakat yang mengharuskan pemerintah untuk 
mampu mengatasi masalah pedagang kaki lima dan salah satu caranya dengan mengadakan relokasi dan penataan. Disisi lain keberdaan Pedagang Kaki Lima tidak selamanya merugikan dan menggangu. Keberadaan pedagang kaki lima jika dilihat dari perannya yang mampu menopang perekonomian rakyat bawah dengan menyediakan barang dengan harga terjangkau, memberikan lapangan kerja serta dapat memberikan sumbangsih secara materil bagi pemerintah. Dengan kata lain keberadaan Pedagang Kaki Lima tidak semertamerta memberikan dampak buruk. Maka dari itu dengan adanya pertimbangan di atas pemerintah seharusnya mampu memberikan kebijakan yang tidak merugikan pihak manapun baik masyarakat maupun Pedagang Kaki Lima itu sendiri.. Seperti hasil wawancara

"sebenarnya pemerintah kota harus menata Pedagang Kaki Lima dengan sebaik mungkin, karena memang apabila Pedagang Kaki Lima ditata dengan baik pasti akan memberikan sumbangsi yang masuk ke PAD (pendapatan asli daerah)"(sumber: Ketua Asosiasi Pedagang Kaki Lima Kota Kendari, wawancara 13 januari 2020)

Keberadaan Pedagang Kaki Lima di Kecamatan Mandonga memang telah menjadi masalah dari tahun ke tahun. Banyaknya jumlah Pedagang Kaki Lima yang terus bertambah walaupun telah di relokasi memenuhi ruas badan jalan, lokasi-lokasi yang ada di Kecamatan Mandonga membuat banyak keluhan yang muncul dari masyarkat. Keberadaan Pedagang Kaki Lima yang tidak tertata, tidak tertib menimbulkan kemacetan serta mengotori jalan dan semakin menambah masalah. Keberadaan Pedagang Kaki Lima yang semakin tidak terkontrol membuat pemerintah harus memutar otak agar keberadaan Pedagang Kaki Lima tidak menjadi gangguan bagi msayrakat namun Pedagang Kaki Lima juga masih tetap menjalankan usahanya dengan nyaman sehingga pemerintah mengelvarkan kebijakan untuk merelokasi pedagang kaki lima ke lahan kosong yang telah disediakan.

Sebenarnya terkait dengan penataan Pedagang Kaki Lima di Kota Kendari terkhusus di Kecamatan Mandonga sudah diatur di dalam Peraturan Walikota Nomor 13 tahun 2008 tentang Penataan Pedagang Kaki Lima yang mana sesuai ketentuan Pasal 12 "Peraturan ini sekaligus sebagai pelimpahan wewenang Kepala Daerah kepada Kepala Dinas Perdagangan, Koperasi dan UKM, Satuan Polisi Pamong Praja dan Camat". Hal ini sesuai dengan hasil wawancara:

"untuk penataan pedagang kaki lima di kota Kendari sudah di atur di dalam Peraturan Walikota Nomor 13 tahun 2008 agar kemudian pedagang kaki lima ini tidak menggangu ketertiban umum dan yang paling penting juga tidak mempengaruhi keindahan kota, karena memang kebanyakan dari mereka berdagang itu masih di bahu-bahu jalan dan trotoar" (sumber: Kasat pol PP Kota Kendari, wawancara 19 Desember 2019)

Para Pedagang Kaki lima juga mengharapkan Kebijakan yang dilakukan oleh Pemerintah Kota Kendari, yaitu sebagaimana Pedagang kaki lima juga ingin mendapatkan ketenangan 
dan dapat berjualan dengan bebas serta tidak adanya Penataan yang dilakukan oleh petugas Trantib, hanya dengan berdagang dan berjualan para pedagang dapat mencari nafkah dan mendapatkan Penghasilan Setiap harinya (sumber: pedagang kaki lima di J. Lasandara samping Mall Mandonga)

Standar kebijakan Penataan Pedagang Kaki Lima adalah berdasarkan Peraturan Presiden Republik Indonesia Nomor 125 Tahun 2012 tentang Koordinasi Penataan dan Pemberdayaan Pedagang Kaki Lima yang menyatakan bahwa Pedagang Kaki Lima sebagai salah satu pelaku usaha ekonomi kerakyatan yang bergerak dalam usaha perdagangan sektor informal, dan perlu dilakukan pemberdayaan untuk meningkatkan dan mengembangkan usahanya, dan bahwa peningkatan jumlah pedagang kaki lima di daerah telah berdampak pada estestika, kebersihan, dan fungsi sarana dan prasarana kawasan perkotaan serta terganggunya kelancaran lalu lintas, perlu dilakukan adanya penataan.

Berdasarkan regulasi tersebut, Pemerintah Kota Kendari mengadobsi dan menetapkan Peraturan Walikota Nomor 13 tahun 2008 tentang Penataan Pedagang Kaki Lima yang mana sesuai ketentuan Pasal 3 peraturan tentang penataan ini diarahkan untuk mewujudkan tertib lingkungan yang serasi, baik dari segi ketertiban umum, kebersihan lingkungan maupun dalam menunjang keindahan kota serta meningkatkan fungsi prasarana, sarana dan utilitas umum dengan harapan dapat mengatasi permasalahn yang ditimbulkan akibat adanya Pedagang Kali Lima di Kota Kendari.

Selanjutnya untuk membatasi ruang limgkup penulisan, maka berikut kami jelaskan pembahasan berdasarkan indikator penelitian yang sudah ditetapkan yaitu Implementasi kebijakan penataan PKL di Kecamatan Mandonga, faktor-faktor yang mempengaruhi dan kendala yang dihadapi dalam implementasi Peraturan Walikota Nomor 13 tahun 2008 tentang Penataan Pedagang Kaki Lima.

\section{Implementasi Kebijakan Penataan PKL di Kecamatan Mandonga}

Untuk mengetahui implementasi kebijakan penataan Pedagang Kaki Lima di Kecamatan Mandonga ini dapat di analisis dengan mengacu pada teori implementasi kebijakan yang di kembangkan oleh Charles $O$. Jones, yang mana ada beberapa tahapan yaitu:

\section{Tahapan Pengorganisasian (Organized)}

Tahapan Pengorganisasian dalam Kebijakan Pemerintah Kota Kendari dalam Penataan Pedagang Kaki lima di Kecamatan Mandonga melibatkan 3 instansi terkait yaitu Dinas Perdagangan, Koperasi dan UKM Kota Kendari, Satuan Polisi Pamong Praja Kota Kendari dan Masing-masing Camat se Kota Kendari yang mana ini sesuai dengan isi Kebijakan pada pasal 12 Peraturan Waikota Kendari Nomor 13 tahun 2008 tentang Penataan Pedagang Kaki lima.

Dalam tahapan pengorganisasian terkait impementasi kebijakan penataan Pedagang Kaki lima di Kecamatan Mandonga dari masing-masing instansi tersebut mempunyai tugas 
masing-masing. Dari hasil wawancara kenyataanya memang tugas dari pada Dinas Perdagangan, Koperasi dan UKM Kota Kendari sudah tercantum dalam isi kebijakan Peraturan Waikota Kendari Nomor 13 tahun 2008 tentang Penataan Pedagang Kaki lima yaitu mengeluarkan TDU PKI ataU Tanda Daftar Usaha Pedagang Kaki lima, akan tetapi TDU PKI ini tidak berjalan dengan maksimal dikarenakan sesuai hasil observasi peneliti di lapangan bahwa hampir tidak ada pedagang kaki lima di Kecamatan Mandonga yang mempunyai TDU PKL ini dikarenakan minimnya informasi yang diterima oleh pedagang kaki lima yang melakukan aktifitasnya di kecamatan Mandonga. Misalnya TDU PKL ini berjalan dengan maksimal otomatis lokasi, aktifitas, waktu operasi, jumla, jenis barang yang diperdagangkan Pedagang kaki lima akan lebih teratur.

Selanjutnya sesuai hasil wawancara dan observasi Satuan Polisi Pamong Praja Kota Kendari selalu melakukan penertiban terhadap Pedagang Kaki Lima yang berada di Kecamatan Mandonga yang selalu melakukan aktivitasnya tidak sesuai dengan ketentuan yang berlaku. Sebenarnya Satuan Polisi Pamong Praja Kota Kendari juga selalu melakukan komunikasi persuasif terhadap pedagang kaki lima agar tidak melakukan aktivitasnya di lokasi-lokasi yang di ilegalkan oleh Pemerintah Kota akan tetapi selalu ada hambatan-hambatan yang di alami oleh Satuan Polisi Pamong Praja Kota Kendari karena berkaitan dengan daya beli masyarakat atau lapangan pekerjaan.

Saat ini sebenarnya ada program yang diluncurkan oleh walikota kendari dimana walikota mengundang seluruh Camat se Kota Kendari dan Para Stakeholder terkait Penataan Pedagang kaki Lima untuk membahas program terkait dengan aktivitas yang dilakukan oleh pedagang kaki lima yang tidak sesuai peraturan yang berlaku. Hal ini sesuai hasil wawancara dan observasi bahwa pada tahapan pengorganisasian yang dilakukakan oleh Pemerintah Kota terkait dengan instansi yang berwenang dalam melakukan penataan pedagang kaki lima sudah melakukan tugasnya masing-masing dan jelas sudah melakukan koordinasi antar instansi, hanya memang masih kurang maksimal dikarenakan juga tidak ada leading sector dari SKPD khusus atau satuan tugas yang di bentuk oleh pemerintah Kota Kendari terkait dengan Penataan pedagang kaki lima.

\section{Tahapan Interprestasi (Interpretation)}

Tahapan Interpretasi merupakan tahapan penjabaran sebuah kebijakan yang lebih bersifat abstrak ke dalam kebijakan yang lebih bersifat teknis operasional. Aktivitas ini juga diikuti kegiatan mengkomunikasikan kebijakan (sosialisasi) agar seluruh elemen masyarakat (stakeholder) dan kelompok sasaran dapat mengetahui dan memahami arah, tujuan, dan sasaran kebijakan. Pada tahapan ni sebenarnya seberapa jauh para implementor kebijakan yakni Dinas Perdagangan, Koperasi dan UKM Kota Kendari, Satuan Polisi Pamong Praja Kota Kendari dan Masing-masing Camat se Kota Kendari mengetahui arah, tujuan dan sasaran 
kebijakan, sebenarnya arah dan tujuan kebijakan penataan pedagang kaki lima ini sudah jelas di isi Peraturan Walikota Nomor 13 tahun 2008 dan adapun sasaran kebijakan ini adalah para pedagang kaki lima.

Dari hasil wawancara dan observasi dapat disimpulkan bahwa Pemerintah Kota sudah melakukan sosialisasi tentang Penataan Pedagang kaki Lima hanya persoalanya bahwa, Pemerintah Kota hanya melakukan relokasi saja ke Pasar-pasar yang ada dan ini yang menjadi mesalah ketika mereka di relokasi tidak ada yang menjamin disana akan ramai pembeli dan rata-rata mereka berjualan dalam kurun waktu yang sangat lama dan ini yang perlu di pikirkan oleh Pemerintah Kota, apakah hanya relokasi yang akan dilakukan oleh Pemeritah Kota atau ada program-program penataan yang lain agar Pedagang Kaki Lima tetap berjualan dan tidak Melanggar isi dari pada kebijakan tersebut dan tidak merugikan pihak manapun. Selanjutnya, Pemerintah Kota atau para implementor kebijakan sudah melakukan sosialisasi kebijakan tersebut hanya saja Pedagang Kaki lima merasa acuh dan tidak taat terhadap aturan yang ada dan bukan tanpa alasan Pedagang Kaki Lima tersebut tidak taat karena ada keraguan yang besar ketika mereka akan direlokasi Ke pasar yang sudah disiapkan oleh Pemerintah Kota. Maka dari itu perlu adanya penataan yang dilakukan oleh Pemerintah Kota agar keberadaan Pedagang Kaki Lima ini tidak memberikan dampak yang negatif seperti kemacetan lalu lintas, kekumuhan Kota dan tidak merebut hak pejalan kaki karena berjualan di trotoar, melainkan dapat mengurangi pengangguran karena adanya lapangan pekerjaan dan dengan keberadaan Pedagang Kaki Lima ada retribusi yang kemudian masuk ke Pendapatan Asli Daerah.

\section{Tahapan Aplikasi (Application)}

Tahap Aplikasi merupakan tahap penerapan rencana proses implementasi kebijakan ke dalam realitas nyata. Tahap aplikasi merupakan perwujudan dari pelaksanaan masingmasing kegiatan dalam tahapan yang telah disebutkan sebelumnya. Tahap aplikasi merupakan tahap paling akhir karena pada tahap ini dapat dilihat apakah kebijakan tersebut hanya sebuah rumusan kebijakan atau penafsiran mengenai kebijakan yang abstrak atau bisa diimplementasikan dan dapat menjawab tantangan berbagai permasalahan yang terjadi dalam masyarakat secara keseluruhan. Pada tahapan ini upaya-upaya yang dilakukan oleh Pemerintah kota Kendari dalam penataan Pedagang Kaki Lima di kecamatan Mandonga yaitu dengan melakukan sosialisasi terkait dengan isi dari pada kebijakan penataan Pedagang Kaki Lima, melakukan penertiban dan pembongkaran tempat usaha apabila memang aktivitas dari Pedagang Kaki Lima tersebut tidak sesuai dengan peraturan yang berlaku. Sebenarnya tidak hanya itu upaya yang dilakukan oleh Pemerintah Kota Kendari ketika pedagang ditertibkan Pedagang tersebut ditunjukkan lokasi-lokasi yang diperbolehkan oleh Pemerintah Kota Kendari.

Sesuai dengan hasil wawancara dan observasi bahwa keberadaan Pedagang kaki lima 
yang melakukan aktivitasnya di lokasi yang ilegal atau tidak ditetapkan oleh Pemerintah Kota telah dilakukan sosialisasi, penertiban, dan pembongkaran tempat usaha akan tetapi hasil observasi peneliti menunjukkan masih begitu banyak Pedagang Kaki Lima yang melakukan aktivitasnya tidak sesuai dengan ketentun yang berlaku, karena memang faktanya bahwa Pedagang Kaki Lima tersebut tidak akan mau pindah ke lokasi yang disiapkan oleh pemerintah Kota terlebih lagi apabila Pedagang tersebut sudah melakukan aktivitasnya dalam kurun waktu yang sangat lama. Sebenarnya upaya yang dilakukan oleh Pemerintah Kota saat ini hanyalah Relokasi Pedagang Kaki Lima ke Peddis Market atau Kawasan Pedagang Kaki Lima dan sesuai hasil observasi apabila semua Pedagang Kaki Lima di relokasi tempat yang disediakan oleh Pemerintah Kota tersebut tidak akan cukup kecuali Pemerintah Kota menyiapkan 1 tempat atau lahan untuk menampung Pedagang Kaki Lima tersebut.

Kalau kita merujuk pada kota-kota besar lainnya bahwa Pedagang Kaki Lima itu diberikan fasilitas-fasilitas yang menunjang untuk aktivitas Pedagang Kaki Lima agar keberadaannya tidak membuat Kota menjadi kumuh dan jelas tidak melanggar sasaran dari penataan Pedagang Kaki Lima pada pasal 2, seperti halnya bantuan tenda, gerobak dan lain-lain dan yang paling penting adalah penetepan lokasi, waktu, barang dagangan, dan jumlah pedagang yang diperboleh untuk berada di kawasan tersebut dan ditetapkan melalui Keputusan Walikota. Kita bisa mengambil contoh seperti di jakarta pusat bahwa Pedagang Kaki Lima yang tidak tertata, kemudian ada program-program penataan yang dilakukakan oleh kepala daerah dengan memberikan bantuan tenda dan penetapaan lokasi yang jelas, sehingga dapat membawa dampak positif baik itu terbukanya lapangan pekerjaan dan ada retribusi untuk Pedagang Kaki Lima yang kemudian menjadi sumber pendapatan daerah.

\section{Faktor- Faktor yang mempengaruhi Implementasi Kebijakan Penataan PKL}

Untuk mengetahui Faktor- Faktor yang mempengaruhi implementasi kebijakan ini dapat di analisis dengan mengacu pada model implementasi kebijakan yang di kembangkan oleh Edward III. Adapun variabel-variabel dalam model ini meliputi:

\section{Komunikasi}

Keberhasilan implementasi suatu kebijakan, menurut Edward III, adalah komunikasi. Komunikasi, menurutnya, sangat menentukan keberhasilan pencapaian tujuan dari implementasi kebijakan publik. Implementasi yang efektif terjadi apabila para pembuat keputusan sudah mengetahui apa yang akan mereka kerjakan.

Dalam penataan Pedagang Kaki Lima di Kecamatan Mandonga melalui instansi terkait telah melakukan berbagai upaya penertiban terhadap Pedagang Kaki Lima yang beraktiitas di lokasi yang dilarang oleh Pemerintah Kota. Berdasarkan observasi peneliti dan 
wawancara dengan Kepala Bidang Penegakan Perda Satpol PP kota Kendari dan Kepala Bidang UKM Dinas Perdagangan, Koperasi dan UKM Kota Kendari, diperoleh informasi bahwa kebijakan yang telah diambil oleh pemerintah kota Kendari berkaitan dengan Pedagang Kaki Lima di Kecamatan Mandonga meliputi:

1) Melakukan sosialisasi terkait dengan Peraturan Walikota Nomor 13 tahun 2008 tentang Pedagang Kaki Lima

2) Melakukan pembinaan terhadap Pedagang Kaki Lima

3) Melakukan pembongkaran terhadap tempat usaha Pedagang Kaki Lima yang tidak sesuai dengan ketentuan yang berlaku

4) Melakukan penertiban dan penataan lokasi Pedagang Kaki Lima

Berdasarkan hasil penelitian berkaitan dengan upaya penataan Pedagang Kaki Lima di Kecamatan Mandonga dapat dikatakan belum efektif. Belum efektifnya yang dilakukan oleh Pemerintah Kota Kendari dalam penataan Pedagang Kaki Lima dapat dilihat dari keberadaan Pedagang Kaki Lima yang masih melakukan aktivitas usahanya di tempattempat yang dilarang oleh Pemerintah Kota Kendari, walaupun memang pemerintah Kota Kendari sudah menyiapkan tempat untuk pedagang kaki lima di pasar peddis market (kawasan pedagang kaki lima).

Secara umum, berdasarkan hasil observasi dan wawancara dapat disimpulkan bahwa komunikasi yang dilakukan oleh pemerintah Kota Kendari memang sudah dilakukan bahkan pada saat Peraturan walikota ini sudah ditetapkan menjadi sebuah kebijakan, baik itu dilakukan oleh Dinas Perdagangan, Koperasi dan UKM Kota Kendari, Sat Pol PP kota Kendari dan Camat, akan tetapi ouputnya masih saja ada pedagang kaki lima yang belum taat aturan walaupun mereka mengetahui larangan berjualan di bahu jalan dan trotoar karena mengganggu dari segi ketertiban umum, kebersihan lingkungan maupun dalam menunjang keindahan kota yang mana ini sesuai dengan isi peraturan pada pasal 3. Hal ini sejalan dengan pemikiran Edward III yang mengatakan informasi kebijakan perlu disampaikan kepada pelaku kebijakan agar pelaku kebijakan dapat mengetahui, memahami apa yang menjadi isi, tujuan, arah, kelompok sasaran kebijakan agar apa yang menjadi tujuan dan sasasaran kebijakan dapat dicapai sesuai dengan yang diharapkan. Maka dapat disimpilkan Komunikasi merupakan faktor pendukung dalam Implementasi kebijakan peraturan walikota nomor 13 tahun 2008 tentang penatan Pedagang Kaki Lima di Kecamatan Mandonga.

\section{Sumberdaya}

Sumber daya memiliki peranan penting dalam implementasi kebijakan. Edward III dalam Widodo (2011 :98) mengemukakan bahwa: bagaimanapun jelas dan konsistensinya ketentuan-ketentuan dan aturan-aturan serta bagaimanapun akuratnya penyampaian ketentuan-ketentuan atau aturan-aturan tersebut, jika para pelaksana kebijakan yang 
bertanggung jawab untuk melaksanakan kebijakan kurang mempunyai sumber daya untuk melaksanakan kebijakan secara efektif maka implementasi kebijakan tersebut tidak akan efektif.

Berkaitan dengan ketersedian sumber daya manusia aparatur pelaksana implementasi kebijakan penataan Pedagang Kaki Lima di Kecamatan Mandonga ada 2 instansi yang berwenang sesuai isi peraturan walikota nomor 13 tahun 2008 pada pasal 13 bahwa peraturan ini sekaligus sebagai pelimpahan kewenangan Kepala Daerah kepada Kepala Dinas Perdagangan, Koperasi dan UKM Kota Kendari dan Satuan Polisi Pamong Praja Kota Kendari yang dapat dilihat pada tabel 2 dan tabel 3 tentang komposisi pegawai berdasarkan jumlah, status kepegawaian dan tingkat pendidikan.

Tabel 2. Jumlah Pegawai Dinas Perdagangan, Koperasi dan UKM Kota Kendari

\begin{tabular}{cccc}
\hline No & Status Kepegawaian & Tingkat Pendidikan & Jumlah \\
\hline & & Pasca Sarjana (S2) & 10 \\
\cline { 3 - 4 } 1 & Pegawai Negeri Sipil & Sarjana (S1) & 29 \\
\cline { 3 - 4 } & Jumlah Pegawai Masing-Masing Bidang & 5 \\
\hline No & Nama Bidang & Jumlah \\
\hline 1 & Bidang Sekertariat & 14 \\
\hline 2 & Bidang Logistik, Distribusi, dan kerjasama & 12 \\
\hline 3 & Bidang Perdagangan & 6 \\
\hline 4 & Bidang UKM & 6 \\
\hline 5 & Bidang Koperasi & 6 \\
\hline
\end{tabular}

Sumber: Dinas Perdagangan, Koperasi dan UKM Kota Kendari 2019

Tabel 3. Jumlah Pegawai Satuan Polisi Pamong Praja Kota Kendari

\begin{tabular}{ccc}
\hline No & Status Kepegawaian & Jumlah \\
\hline 1 & Pegawai Negeri Sipil & 72 \\
\hline 2 & Honorer & 359 \\
\hline & Jumlah & 431 \\
\hline
\end{tabular}

Sumber: Sat Polisi Pamong Praja Kota Kendari 2019

Berdasarkan data tabel 2 dan tabel 3, keadaan kepegawaian pada 2 (dua) instansi dapat dikatakan dari segi kualitas dan kuantitas sumberdaya manusia terpenuhi, hanya saja belum memadai dikarenakan khusus penataan pedagang kaki lima distribusi wewenang kepada Bidang UKM perlu melibatkan stakeholders lainnya sehinnga kita dapat melihat keseriusan pemerintah daerah untuk melaksanakan regulasi yang sudah ditetapkan.

Sumber daya lain yang menjadi kendala dalam kebijakan penataan Pedagang Kaki Lima di Kecamatan Madonga berkaitan dengan sumber daya peralatan dan sumber daya anggaran. Hasil penelitian dilapangan menunjukan bahwa sumber daya peralatan yaitu berhubungan dengan tempat atau fasilitas yang dapat disediakan oleh Pemerintah Kota Kendari guna penempatan Pedagang Kaki Lima masih terbatas atau belum sesuai dengan 
kebutuhan. Kenyataan ini dapat terlihat dari lokasi atau tempat yang dapat disediakan oleh Pemerintah Kota untuk diadakan relokasi Pedagang Kaki Lima di Kecamatan Mandonga hanya 2 (dua) lokasi saja dan itupun lokasi tersebut sudah padat pedagang dan kemungkinan besar tidak mampu menampung jumlah pedagang kaki lima yang ada saat ini, seharusnya Pemerintah Kota menyiapkan lokasi yang baru dan strategis untuk pedagang kaki lima yang akan di relokasi nantinya, walaupun memang memerlukan anggaran yang cukup besar terutama berkaitan dengan pembebasan lahan dan pembangunan gedung dan fasilitas pendukung lainnya.

Dari hasil observasi dan wawancara dapat disimpulkan bahwa implementasi kebijakan penataan pedagang kaki lima di Kecamatan Mandonga terkait sumber daya dan peralatan atau fasilitas terutama berhubungan dengan penyediaan tempat atau lokasi usaha bagi Pedagang Kaki Lima di Kecamatan Mandonga masih terbatas dan belum sesuai dengan kebutuhan. Begitu pula dengan sumber daya finansial atau anggaran dalam penataan Pedagang Kaki Lima di Kecamatan Mandonga masih terbatas.

\section{Disposisi}

Salah satu faktor yang mempengaruhi efektifitas implementasi kebijakan adalah sikap implementor. Jika implemetor setuju dengan bagian-bagian isi dari kebijakan maka mereka akan melaksanakan dengan senang hati tetapi jika pandangan mereka berbeda dengan pembuat kebijakan maka proses implementasi akan mengalami banyak masalah.

Berdasarkan hasil wawancara dan pengamatan, terjadi miss persepsi dalam implementasi kebijakan Peraturan Walikota nomor 13 tahun 2008 tentang penatan Pedagang Kaki Lima dengan pedagang kaki lima. Pejelasan yang sampaikan oleh Sat Pol PP Kota Kendari bahwa telah melakukan Pengawasan dan sosialisasi persuasif terhadap Pedagang Kaki Lima yang dulunya hanya dilakukan pagi hari kini dilakukan sepanjang jam kerja yaitu mulai pagi, siang dan sore agar kemudian bisa mengurangi keberadaan Pedagang Kaki Lima yang melanggar isi dari Kebijakan peraturan walikota nomor 13 tahun 2008 tentang penatan Pedagang Kaki Lima di Kecamatan Mandonga. Selanjutnya, berbeda dari hasil observasi dan wawancara peneliti ke pedagang kaki lima yang banyak mengatakan bahwa mereka tidak mengetahui tentang TDU PKL ini karena memang jelas kebanyakan dari mereka berjualan di lokasi yang dilarang oleh pemerintah dan kalau misalnya lokasinya mereka ditentukan oleh Camat setempat maka otomatis penataannya itu lebih baik lagi. Sebenarnya TDU PKL ini di atur dalam Peraturan Walikota Nomor 13 tahun 2008 pada Pasal 7 yang mana setiap Pedagang Kaki Lima mengajukan permohonan ke Paguyuban Pedagang Kaki Lima dan Camat setempat untuk di berikan rekomendasi ke Dinas Perdagangan, Koperasi dan UKM Kota Kendari, tetapi ada persyaratan tertentu ketika ingin memiliki TDU PKL ini yaitu harus jelas lokasi yang akan digunakan, jenis barang yang akan diperdagangankan, dan alat perga yang akan digunakan oleh Pedagang Kaki Lima tersebut. Tetapi hasil 
observasi peneliti di lapangan bahwa tidak ada sama sekali Pedagang Kaki Lima yang memiliki TDU PKL ini, karena memang mereka tidak mengetahui apa itu TDU PKL.

Dari hasil observasi dan wawancara diatas dapat disimpulkan bahwa para implementor kebijakan mempunyai sikap yang sungguh-sungguh dalam mengimplementasikan kebijakan tentang penataan pedagang kaki lima, hanya saja memang regulasi yang sudah ditetapkan pemerintah untuk penataan Pedagang Kaki Lima ini minim informasi yang diterima oleh pedagang kaki lima tentang penetapan lokasi yang diperbolehkan oleh pemerintah kota, tetapi sudah mulai ada strategi baru yang dilakukan oleh Pemerintah Kota seperti melakukan Rapat dengan seluruh Camat se Kota Kendari dalam membahas tentang penataan pedagang kaki lima, yang mana seluruh Camat se Kota Kendari diberikan tugas untuk melakukan investigasi terhadap lokasi-lokasi yang digunakan pedagang kaki lima untuk melakukan aktivitasnya. Apabila melihat kenyatan di lapangan, maka dapat dikatakan Pemerintah Kota Kendari sangat serius dalam penatan Pedagang Kaki Lima, hal ini juga terlihat dari berbagai upaya yang dilakukan oleh Pemerintah Kota Kendari, seperti melakukan penertiban dan pembongkaran terhadap pedagang kaki llima yang melanggar aturan, serta menyiapkan lokasi kepada pedagang kaki lima yang sudah di tetapkan oleh pemerintah.

\section{Struktur Birokrasi}

Keberhasilan implementasi kebijakan publik adalah struktur birokrasi. Walaupun sumber-sumber daya untuk melaksanakan suatu kebijakan tersedia, atau para pelaksana kebijakan mengetahui apa yang seharusnya dilakukan, dan mempunyai keinginan untuk melaksanakan suatu kebijakan, kemungkinan kebijakan tersebut tidak dapat terlaksana atau terealisasi karena terdapat kelemahan dalam struktur birokrasi. Kebijakan yang begitu kompleks menuntut adanya kerjasama banyak orang, ketika struktur birokrasi tidak kondusif pada kebijakan yang tersedia, maka hal ini akan menyebabkan sumber-sumber daya menjadi tidak efektif dan tidak termotivasi sehingga menghambat jalannya kebijakan. Birokrasi sebagai pelaksana sebuah kebijakan harus dapat mendukung kebijakan yang telah diputuskan secara politik dengan jalan melakukan koordinasi dengan baik.

Dari hasil wawancara dan observasi menunjukkan bahwa struktur birokrasi dalam implementasi kebijakan penataan pedagang kaki lima di Kecamatan Mandonga telah melibatkan beberapa instansi terkait dan berbagai stakeholder yang berhubungan dengan penataan pedagang kaki lima di Kecamatan Mandonga. Hal ini bisa dilihat dari bebagai bentuk kordinasi yang dilakukan ketika melakukan sosialisasi, penertiban, pembinaan dalam rangka untuk keberhasilan implementasi kebijakan penataan Pedagang Kaki Lima dan ini sejalan dengan isi dari Peraturan Walikota Nomor 13 tahun 2008 pada pasal 12 yaitu 
Kordinasi dari Dinas Perundistrian, Perdagangan, Koperasi dan UKM Kota Kendari, Sat Pol PP Kota Kendari dan masing-masing Camat se Kota Kendari.

Kordinasi merupakan faktor yang sangat dominan di dalam kehidupan suatu organisasi. Oleh karena itu, kordinasi harus secara terus-menerus ditingkatkan dalam rangka mencapai tujuan organsasi secara optimal sebagaimana diketahui bahwa setiap individuindividu dan organisasi memiliki tujuan. Untuk mencapai tujuannya, orang-orang atau bagian-bagian tergabung dalam organisasi dan pihak-pihak yang terkait dengan pencapaian tujuan. Pada kegiatan yang lebih luas dan kompleks kordinasi ini semakin menjadi penting, mengingat dalam era globalisasi tidak satupun unit kerja atau organisasi yang dapat mencapai tujuan tanpa melakukan kordinasi dengan unit kerja yang lain.

\section{Kendala-kendala yang dihadapi Pemerintah Kota Kendari dalam Penataan Pedagang Kaki Lima di Kecamatan Mandonga}

Fenomena Pedagang Kaki Lima telah banyak menyita perhatian Pemerintah. Pedagang Kaki Lima sering kali dianggap mengganggu ketertiban lalu lintas, merampas hak para pejalan kaki akibat digunakannya trotoar, dan tata ruang kota yang kacau. Pemerintah sebagai pembuat kebijakan harus bersikap tegas dalam menentukan kebijakan, namun dalam penegakan dan penertiban kebijakan Pemerintah juga sangatlah sulit dikarenakan berbenturan dengan masalah kemanusian. Permasalahan Pedagang Kaki Lima menjadi menarik, karena Pedagang Kaki Lima menjadi sebuah dilema tersendiri bagi Pemerintah. Disatu sisi Pedagang Kaki Lima sering mengganggu lalu lintas dan tidak sesuai dengan tata ruang kota, disisi lain Pedagang Kaki Lima menjalankan peran sebagai bayangan ekonomi dan lapangan pekerjaan yang belum bisa disediakan Pemerintah.

Kegiatan penataan bagi Pedagang Kaki Lima merupakan kesulitan tersendiri bagi Pemerintah. Selain jumlahnya yang semakin banyak, keberadaan merekapun dipengaruhi aspek ekonomi. Problematika dalam penataan pedagang kaki lima adalah bahwa jumlah mereka yang sangat banyak dan memerlukan ruang yang cukup besar untuk menampung mereka agar dapat tertata. Pemerintah Kota Kendari sendiri melakukan penataan bagi Pedagang Kaki Lima dengan cara menyediakan tempat relokasi untuk para Pedagang Kaki Lima dalam menjalankan kegiatan usahanya.

Adapun upaya yang telah dilakukan oleh Pemerintah Kota Kendari dalam implementasi Kebijakan Peraturan Walikota Nomor 13 Tahun 2008 Tentang Penataan Pedagang kaki Lima di Kecamatan Mandonga mengalamai hambatan dan kendala. Adapun hambatan dan kendala Pemerintah Kota Kendari dalam melakukan Penertiban dan Penataan Pedagang Kaki Lima di Kecamatan Mandonga, diantaranya sebagai berikut:

1. Keterbatasan Sumber daya manusia implementor kebijakan yaitu Dinas Perdagangan, Koperasi dan UKM Kota Kendari dan Sat Pol PP Kota Kendari yang dapat dilihat dari tabel 2 dan tabel 3, Keterbatasan Sumber daya implementor kebijakan ini memberikan 
pengaruh terhadap pengawasan, penertiban dan Penataan terhadap Pedagang Kaki Lima yang melakukan aktivitasnya yang melanggar isi Peraturan Walikota tersebut, Faktanya bahwa keberadaan Pedagang Kaki Lima bukan hanya ada di Kecamatan Mandonga, tetapi di seluruh Kota Kendari. Seharusnya Pemerintah Kota membetuk Tim yang beranggotakan Seluruh stakeholder yang ada di setiap kecamatan agar mempermudah implementasi kebijakan tersebut. Selanjutnya Keterbatasan anggaran untuk menunjang fasilitas yang akan dipergunakan para Pedagang Kaki Lima di Kecamatan Mandonga apabila akan diadakan relokasi ke tempat yang disediakan oleh Pemerintah Kota Kendari. Sesuai dengan hasil observasi peneliti bahwa apabila seluruh Pedagang Kaki Lima yang ada di 8 titik se Kecamatan Mandonga akan di relokasi Maka lokasi yang di tetapkan oleh Pemerintah Kota yakni Pasar basah Mandonga dan Peddis market tidak akan mampu menampung semua pedagang. Maka perlu ada lokasi baru yang harus di alokasikan nantinya untuk Pedagang Kaki Lima.

2. Banyaknya Pedagang Kaki Lima yang tidak memiliki TDU PLK ataU Tanda Daftar Usaha Pedagang Kaki Lima, yang mana seharusnya Pedagang Kaki Lima wajib memiliki TDU PKL yang di atur dalam Peraturan Walikota Kendari Nomor 13 Tahun 2008 pada Pasal 7 karena apabila Pedagang Kaki Lima memiliki TDU PKL di pastikan bahwa mereka merupakan Pedagang yang Legal.

3. Adanya penolakan dari Pedagang Kaki Lima dikarenakan kekawhatiran ketika mereka akan di relokasi ke tempat yang disediakan oleh Pemerintah Kota Kendari mengakibatkan pendapatan mereka tidak sesuai yang diharapkan. Apalagi kebanyakan Pedagang Kaki Lima sudah berjualan dengan kurun waktu yang sudah sangat lama dan kebanyakan dari mereka melakukan aktifitasnya itu di lokasi yang ramai atau di tempat yang banyak di kunjungi oleh masyarakat. Maka dari itu Pengadaan tempat relokasi yang strategis berada di tempat keramaian bagi pedagang kaki lima sehingga mereka tidak sulit untuk mendapatkan pembeli dan kembali lagi ke tempat semula.

4. Masih banyak Pedagang Kaki Lima yang belum paham tentang isi kebijakan Pemerintah Nomor 13 tahun 2008 tentang Penataan Pedagang Kaki Lima yang mengakibatkan mereka melakukan aktifitasnya bukan pada tempat yang di tetapkan oleh Pemerintah Kota Kendari. 


\section{KESIMPULAN}

Berdasarkan apa yang telah diuraikan dalam hasil penelitian, maka dapat ditarik kesimpulan bahwa dalam implementasi kebijakan Peraturan Walikota Kendari Nomor 13 tahun 2008 tentang penataan Pedagang Kaki Lima di Kecamatan Mandonga yang dilakukan oleh instansi terkait yaitu Dinas Perdagangan, Koperasi dan UKM Kota Kendari, Satuan Polisi Pamong Praja Kota Kendari dan Masing-masing Camat se Kota Kendari bisa dikatakan belum maksimal dikarenakan belum tepatnya tujuan, maksud dan sasaran kebijakan yang diatur dalam Peraturan Walikota Kendari Nomor 13 tahun 2008 tentang penataan Pedagang Kaki Lima, yang mengakibatkan Pedagang kaki Lima melakukan aktivitasnya bukan pada tempatnya atau tempat yang dilegalkan oleh Pemerintah Kota Kendari.

\section{SARAN}

Berdasarkan atas hasil penelitian dan kesimpulan yang telah dipaparkan di depan, maka dapat disampaikan saran-saran sebagai berikut :

1. Dalam mengetahui seberapa besar keberhasilan implementasi Peraturan Walikota Nomor 13 tahun 2008 tentang Penataan Pedagang Kaki Lima seharusnya Pemerintah Kota Kendari melakukan pendataan tiap tahunnya terhadap Pedagang Kaki Lima yang legal, ilegal, dan pedagang yang sudah di relokasi sehingga kita bisa mengatuhui jumlah dan dari jumlah ini kita bisa mengetahui keberhasilan Penataan tiap tahunnya.

2. Sering diadakannya sosialisasi dan pembinaan kepada pedagang kaki lima tentang peraturan yang terkait dengan program penataan pedagang kaki lima, dan komunikasi yang baik antara petugas dan kelompok sasaran sehingga sedikit demi sedikit akan tumbuh kesadaran mereka terhadap peraturan.

3. Dalam Penataan Pedagang Kaki Lima di Kecamatan Mandonga untuk masa yang akan datang sebaiknya Pemerintah Kota Kendari dapat mengalosasikan dana sesuai dengan kebutuhan pengadaan sarana dan prasarana penempatan Pedagang Kaki Lima di Kecamatan Mandonga.

4. Sebaiknya Pemerintah Kota Kendari membuat tim khusus yang melibatkan semua Stakeholder yang berkaitan dengan penataan Pedagang Kaki Lima agar proses implementasi kebijakan ini lebih efektif.

5. Seharusnya Pemerintah Kota menetapkan lokasi yang mana diperbolehkan untuk aktifitas Pedagang Kaki Lima dan lokasi yang tidak boleh ada aktifitas Pedagang Kaki Lima dalam bentuk Keputusan Walikota.

6. Seharusnya dilakukan revisi Peraturan Walikota Kendari Nomor 13 tahun 2008 tentang Penataan Pedagang Kaki Lima karena memang lemahnya di peraturan tersebut tidak ada hukum yang mengikat bagi Pedagang Kaki Lima yang tidak aturan dan Kuranganya Penjabaran Lokasi yang ditetapkan oleh Pemerintah Kota serta kurang jelasnya tugas dan wewenang SKPD terkait. 


\section{DAFTAR PUSTAKA}

Adam Ramadhan. (2015). Model Zonanisasi Penataan Pedagang Kaki Lima Di Kota Bandung (Prespektif Peraturan Daerah Kota Bandung Nomor 4 Tahun 2011 Tentang Penataan Dan Pembinaan Pedagang Kaki Lima). Semarang. Unnes Law Journal

Anton Sudjarwo. (2012). Kebijakan Publik Dalam Pelaksanaaan Penataan Pola Pedagang Kaki Lima Di Kota Malang. Jawa Timur. Jurnal Revormasi

Bahtiar Bahar.(2018). Implementasi Kebijakan Strategi Pengelolaan Bagi Pedagang Kaki Lima Kota Makassar. Makassar.

Bambang Sunggono. 1994. Hukum Dan Kebijaksanaan Publik. Jakarta: Sinar Grafika.

Eka Evita. (2016). Implementasi Kebijakan Penataan Pedagang Kaki Lima (Studi Pada Batu Tourism Center Di Kota Batu). Malang. Jurnal Administrasi Publik

Haeruddin.(2019) Implementasi Kebijakan Penataan Pedagang Kaki Lima (Pkl) Di Kota Kendari Provinsi Sulawesi Tenggara.Sulawesi Tenggara. Sultra Jurnal Of Political Science

La Ode Mustafa. Implementasi Program Relokasi Pasar Dan Kondisi Sosial Ekonomi Pedagang (Studi Kasus Pasar Sentral Wua-Wua Kendari). Kendari.

La Ode Muhammad Elwan, S. (2011). IMPLEMENTASI PERDA KOTA KENDARI NO. 15 TAHUN 2003 TENTANG PARTISIPASI MASYARAKAT DALAM PERUMUSAN KEBIJAKAN DAERAH PADA PENYUSUNAN ANGGARAN PENDAPATAN BELANJA DAERAH TAHUN 2010. Universitas Gadjah Mada.

Handam. (2016). Peran Pemerintah Daerah Dalam Pelaksanaan Penataan Pedagang Kaki Lima Di Pasar Minasamaupa Kabupaten Gowa. Makassar. Jurnal Ilmu Pemerintahan

Santosa, Panji, Administrasi Publik Terori dan Aplikasi Good Governance. PT Revika Aditama.2017

Setioningsih. Partisipasi Forum Anak dalam Implementasi Kebijakan Kelurahan Layak Anak di Kota Surakarta (Studi Tentang Partisipasi Forum Anak Jebres di Kelurahan Jebres). Jurnal Wacana Publik. 2017

Sugiyono. (2011). Penelitian Kualitatif Kuantitatif Dan R\&D. Bandung: Alfabeta.

Moleong, Lexy J. (2007). Metodologi Penelitian Kualitatif. Bandung: Pt. Remaja Rosdakarya

Wirnano Budi.(2007). Teori Dan Proses Kebijakan Public.Yogyakarta. Media Pressendo

Muhammad Abdulrohman Najib, "Implementasi Peraturan Daerah Kabupaten Magelang No 7 Tahun 2009 Tentang Penataan Dan Pemberdayaan Pedagang Kaki Lima". Skripsi Fakultas Ilmu Social Universitas Negeri Yogyakarta, 2012.

Nursamsi Dwi Safitri, "Analisis Penataan Pedagang Kaki Lima Dikabupaten Maros". Skripsi Fakultas IImu Social dan IImu Politik Universitas Hasanuddin Makassar, 2015.

Undang-undang No. 13 tahun 2008 tentang penataan pedagang kaki lima

Peraturan Menteri dalam Negeri Republik Indonesia No. 41 tahun 2012 tentang Pedoman Penataan dan Pemberdayaan Pedagang Kaki Lima. 